\title{
Phosphorus and Boron Application on Growth, Yield, and Quality of Soybean Seeds (Glycine max [L.] Merril)
}

\author{
Paul Benyamin Timotiwu ${ }^{1}$, Agustiansyah ${ }^{1}$, Eko Pramono $^{1}$ \& Steffy Agustin ${ }^{1}$ \\ ${ }^{1}$ University of Lampung, Lampung, Indonesia \\ Correspondence: Paul Benyamin Timotiwu, University of Lampung, Jalan Prof. Soemantri Brodjonegoro, No. 1, \\ Bandar Lampung 35145, Indonesia. E-mail: paul.timotiwu@outlook.com
}

Received: March 14, 2018

Accepted: April 23, $2018 \quad$ Online Published: May 15, 2018

doi:10.5539/jas.v10n6p372

URL: https://doi.org/10.5539/jas.v10n6p372

\begin{abstract}
The increased of growth, yield and quality of soybean seeds are expected to occur by applyingP (phosphorus) and $\mathrm{B}$ (boron). This research was to investigate the effect of $\mathrm{P}$ and application of $\mathrm{B}$ their response on growth, yield and quality of soybean seeds. This research was conducted at fieldland and the Laboratory of Seeds and Plant Breeding, Faculty of Agriculture, University of Lampung from November 2016 to April 2017. This treatment was arranged in a $6 \times 2$ factorial consisting of six doses of $\mathrm{P}_{2} \mathrm{O}_{5}(0 ; 50 ; 100 ; 150 ; 200 ; 250 \mathrm{~kg} / \mathrm{ha})$ and two concentration of B $(0$ and $5 \mathrm{ppm}$ ). This study was designed in Randomized Complete Block Design (RCBD) with three blocks. Homogeneity of variance was tested by Barlett's test and non-aditivity model using Tukey's test and continued by orthogonal polynomials at $\alpha 0.05$. The results showed that applying P to dose $250 \mathrm{~kg} / \mathrm{ha}$ increase the growth, yield and quality of soybean seeds in all variables. Whereas the applications $5 \mathrm{ppm}$ of Boron increased growth, yield and quality of soybean plant seeds higher than without Boron on avariable number of unfallleaf, dry weight of plant, 100 grain weight, germination, dry weight of normal seedling, and vigor index. Response of growth, yield and quality of soybean seeds to increased doses of $\mathrm{P}$ did not depend on the granting of B.
\end{abstract}

Keywords: boron, phosphorus, soybean

\section{Introduction}

Soybean (Glycinemax [L.] Merrill) has been put as the the first place of high quality vegetable protein source in the world. It is widely spread and grew well in any regions such as United States, Brazil, China, Mexico, and Indonesia. Soybean is the third strategic commodity in Indonesia after paddy and maize, because the average consumption level reached $8.73 \mathrm{~kg} /$ capita/year (CBS, 2017).

According Julita et al. (2016), the high demand of soybean must be supported by high soybean productivity, one of the way to increase growth, yield and quality of soybean plant seeds is by improving the fertilizer. Phosporus fertilizer can activate enzyme that has played role in photosynthesis in plant. In the stage, this process will improve photosynthate accumulation resulted including one that is stored in seeds (Permadi \& Haryati, 2015). According to Sihaloho et al. (2012), phosphorus fertilization can accelerate flowering and ripening of fruits, seeds or grains.

In addition to macro nutrients such as phosphorus, micro-nutrients are also essential nutrients for plants (Sudaryono, 2017). According to Rio Tinto (2012), one of micro elements, which are crucial for plants, is boron because boron plays a role in carbohydrate metabolism, role in the producing grain, strengthens cell wall structure, and stimulates specific metabolic pathways, increasing the transport of carbohydrates and increasing the enzyme activity. Agustina (2011) said levels of boron in plants averaged $20.0 \mathrm{ppm}$ while the availability of boron content is generally only about $5 \%$ of the total content in the soil ranging between $7-80 \mathrm{ppm}$.

This study was to determine the effect of phosphorus fertilization and application of boron through the leaves on the growth, yield and quality of soybean seeds.

\section{Material and Methods}

This study was conducted at the Integrated Field Laboratory and Laboratory of Seeds and Plant Breeding, Faculty of Agriculture, University of Lampung from November 2016 to April 2017. 


\subsection{Implementation Research}

Preparation of Media for Planting: The kind of soil that used is ground Ultisol. Soil is put into polybags and weighed approximately $8 \mathrm{~kg}$ of each. 72 polybags are used. There were 12 polybags which have been filled the Ultisol soil per group.

Planting: Soybeans seeds were grown in polybags filled by planting media. Planting done by immersing the seed into polybags containing media for planting to a depth of $3 \mathrm{~cm}$. The seeds were planted as much as 5 grains of seed in each polybag. It was aimed to get the plant which has the best growth rate and to prevent failure to grow of a seed planted. One week after planting, selection of similar plant growth was conducted by selecting 3 similar growth plants and those plants were put into one polybag.

Fertilization: Phosphorus application was given with interval $0 \mathrm{~g} \mathrm{TSP} / 8 \mathrm{~kg}$ of soil equivalent to $0 \mathrm{~kg} / \mathrm{ha}$ of $\mathrm{P}_{2} \mathrm{O}_{5}$; $0.43 \mathrm{~g} \mathrm{TSP} / 8 \mathrm{~kg}$ of soil equivalent to $50 \mathrm{~kg} / \mathrm{ha}$ of $\mathrm{P}_{2} \mathrm{O}_{5} ; 0.87 \mathrm{~g} \mathrm{TSP} / 8 \mathrm{~kg}$ of soil was equivalent to $100 \mathrm{~kg} / \mathrm{ha}$ of $\mathrm{P}_{2} \mathrm{O}_{5}$; $1.30 \mathrm{~g} \mathrm{TSP} / 8 \mathrm{~kg}$ of soil was equivalent to $150 \mathrm{~kg} / \mathrm{ha}$ of $\mathrm{P}_{2} \mathrm{O}_{5} ; 1.74 \mathrm{~g} \mathrm{TSP} / 8 \mathrm{~kg}$ of soil was equivalent to $200 \mathrm{~kg} / \mathrm{ha}$ of $\mathrm{P}_{2} \mathrm{O}_{5}$; and $2.17 \mathrm{~g} \mathrm{TSP} / 8 \mathrm{~kg}$ of soil was equivalent to $250 \mathrm{~kg} / \mathrm{ha}$ of $\mathrm{P}_{2} \mathrm{O}_{5}$; fertilizer was applied $2 \mathrm{WBP}$ (Weeks Before Planting). Urea fertilizer and $\mathrm{Kcl}$ respectively as much as $0.4 \mathrm{~g} / 8 \mathrm{~kg}$ is equivalent to $100 \mathrm{~kg} / \mathrm{ha}$ was applied to 2 PM WAP (Weeks After Planting).

Application of Boron: Spraying boron was done since the plant was 21 Days After Planting (DAP). Boron was applied 4 times, respectively by age $28,35,42$, and 49 Weeks After Planting (WAP) with a concentration of 0 ppm and $5 \mathrm{ppm}$ is equivalent to $0 \mathrm{~g}$ and $0.028 \mathrm{~g}$. The need of Boron was adjusted by spray volume used at each time of application. Dissolved Boron was sprayed onto the entire surface of the bottom leaf using a hand sprayer. Applications of dissolved Boron was done in the morning to avoid evaporation by the sunlight.

Harvest: Harvesting was done when the plant was 88 days old. At this age the pods have reached physiological ripening. Harvesting was done by removing the soybeans from polybags. Trimmed crops were collected and dried to a moisture content of about $13 \%$. It aimed to facilitate the threshing of seeds.

\subsection{Plant Growth}

Plant Height $(\mathrm{cm})$ : Plant height was measured from the base of the stem to growth point at the end of the vegetative growth of soybean plants. Measurements were performed in centimeters by using meter when plants was 7 WAP (Weeks After Planting).

Number of Leaf Fall: Number of leaves fall was determined by counting the leaf fall, the leaf yellowing and was about to fall when the trees reached 7 WAP (Weeks After Planting).

Number of Leaf Unfall: Number of leaf unfall was determined by counting the leaves unfall or still attached to soybean plants. Observations were made when plants are aged 7 WAP (Weeks After Planting).

Dry Weight of Plant (g): Dry weight was obtained by weighing dried plant soybeans during early phase of pods charging. The drying was done using the oven with temperature $70{ }^{\circ} \mathrm{C}$ during $3 \times 24$ hours. The measurement was in gram.

\subsection{Plant Yield}

Total Number of Pods: Observations were made at the time of the harvest by calculating the total number of unfilled and filled. Calculations was carried out in units of pods per plant.

Number of Filled Pods: Observations were made at harvest time by counting a total of pods per plant. Total count of filled pods were then separated from the unfilled pods. Calculations were carried out in units of pods.

100-Grain Weight: Observations were carried out by counting the seeds using a seed counters to 100 grains, weight was measured in $12 \%$ moisture content in units of gram.

\subsection{Quality of Seeds}

Germination Test: The method used for germination test was based on ISTA (2010) namely rolled paper test by using plastic. Soybean seeds (25 grains) from each treatment were put on two layers of moist CD paper then covered with two layers of it (Fitriesa et al., 2017). It was rolled in moist condition then placed in germinator of IPB type $71-2 \mathrm{~A}$ with room temperature $\left(26 \pm 0.4{ }^{\circ} \mathrm{C}\right)$. First count observation awas conducted on the 5 th day after planting and second count observation was done after the 7 th day.

$$
\mathrm{GP}(\%)=\frac{\sum(\text { Nomal seedling count } \mathrm{I}+\text { Normal seedling count II })}{\sum \text { Seeds planted }} \times 100 \%
$$


Dry Weight of Normal Seedling: The five samples of normal seedlingwere put in envelopes then put in oven temperature $70{ }^{\circ} \mathrm{C}$ for $2 \times 24 \mathrm{~h}$, then measured in weight using electrical balance.

Vigor Index: Index of vigor was measured based on the number of normal seedling on first count with formulas (Copeland \& McDonald, 2001),

$$
\text { VI }(\%)=\frac{\sum \text { Normal seedling first count }}{\sum \text { Seeds planted }} \times 100 \%
$$

\subsection{Experimental Design}

This study was arranged factorially $(6 \times 2)$ in randomized complete block design $(\mathrm{RCBD})$. Factor "A" were two concentrations of $\mathrm{B}(0$ and $5 \mathrm{ppm})$. The factor "B" were six doses of $\mathrm{P}_{2} \mathrm{O}_{5}(0 ; 50 ; 100 ; 150 ; 200 ; 250 \mathrm{~kg} / \mathrm{ha})$. Each treatment was repeated 3 times.

Homogeneity of variance was tested by Barlett's test and non-additivity for linear additive model was tested by Tukey's test and continued by orthogonal polynomials at $\alpha 0.05$. The grouping was based on the planting day with intervals of 2 days.

\section{Results and Discussion}

\subsection{Responses of Plant Growth}

The observation on soybean growth components included plant height, number of leaf fall, number of leaf unfall, and dry weight. The results showed that the response of soybean growth to increased of doses $\mathrm{P}$ did not depend on the application of B as shown by all variables of growth (Table 1).

Table 1. Recapitulation of the effect an increase in the dose of $\mathrm{P}$ and the addition of $\mathrm{B}$ on soybean growth

\begin{tabular}{|c|c|c|c|c|}
\hline \multirow{2}{*}{ Comparation } & \multicolumn{4}{|c|}{ Variable } \\
\hline & PH & $\mathbf{L F}$ & LUF & PW \\
\hline & ---- & --------- & erence -- & -------- \\
\hline \multicolumn{5}{|l|}{ Boron (B) } \\
\hline P1: $\mathrm{B}_{0}$ vs $\mathrm{B}_{1}$ & Ns & $-11.79 *$ & $5.96 *$ & $8.47 *$ \\
\hline \multicolumn{5}{|l|}{ Po (Phosphorus) } \\
\hline P2: Po-Linear & $*$ & $*$ & $*$ & $*$ \\
\hline P3: Po-Quadratic & Ns & ns & $*$ & ns \\
\hline Interaction & Ns & ns & ns & ns \\
\hline P7: P1×P2 & Ns & ns & ns & ns \\
\hline P8: P1×P3 & Ns & ns & ns & ns \\
\hline
\end{tabular}

Note. $\mathrm{B}_{0}=0 \mathrm{ppm} \mathrm{B}, \mathrm{B}_{1}=5 \mathrm{ppm} \mathrm{B}, \mathrm{PH}=$ plant height, $\mathrm{LF}=$ number of leaf fall, $\mathrm{LUF}=$ number of leaves unfall, $\mathrm{PW}$ $=$ dry weight of plant, ${ }^{*}=$ significantly different at $\alpha 0.05$, ns $=$ not significant.

Plant Height (cm): The results showed that application of $\mathrm{P}_{2} \mathrm{O}_{5}$ with dose to $250 \mathrm{~kg} / \mathrm{ha}$ improved soybean plant height. At the dose of $\mathrm{P}_{2} \mathrm{O}_{5} 50 \mathrm{~kg} / \mathrm{ha}$, soybean plant height reached $43.59 \mathrm{~cm}$ and increased $3.8 \mathrm{~cm}$ for every additional $50 \mathrm{~kg}$ of $\mathrm{P}_{2} \mathrm{O}_{5}$ (Figure 1). Application $\mathrm{B}$ with a concentration of $5 \mathrm{ppm}$ produced plants with height which was not different from without B (Table 1). The results are in paralel with Jayasumarta (2012) which stated that the real effect of different levels of fertilizer $\mathrm{P}$ on soybean plant height variables. 


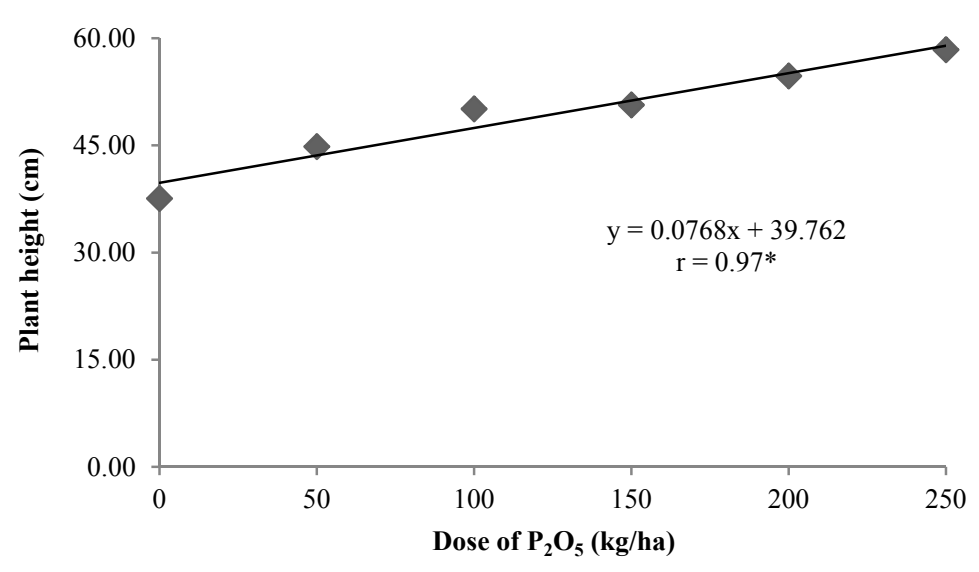

Figure 1. Response curve of the increasing dose of phosphorus on plant height

Number of Leaf Fall (Leaf): Increased dose of $\mathrm{P}$ was able to reduce the number of leaf fall on soybean plants. At the dose of $100 \mathrm{~kg} / \mathrm{ha}$ of $\mathrm{P}_{2} \mathrm{O}_{5}$, the number of leaf fallwas 5 and reduced 1 leaf every additional $100 \mathrm{~kg}$ of $\mathrm{P}_{2} \mathrm{O}_{5}$ (Figure 2). Soybean plants applied with 5 ppm B produced the number of leaf fall at $11.79 \%$ lower than those without $\mathrm{B}$ (Table 1). This is because the function $\mathrm{P}$ is also related to the hardness of the plant leaf so that the leaves do not easily fall. This is in line with research Razaq et al. (2017) which states that the leaf is lack of P had lower chlorophyll content, and easy to fall.

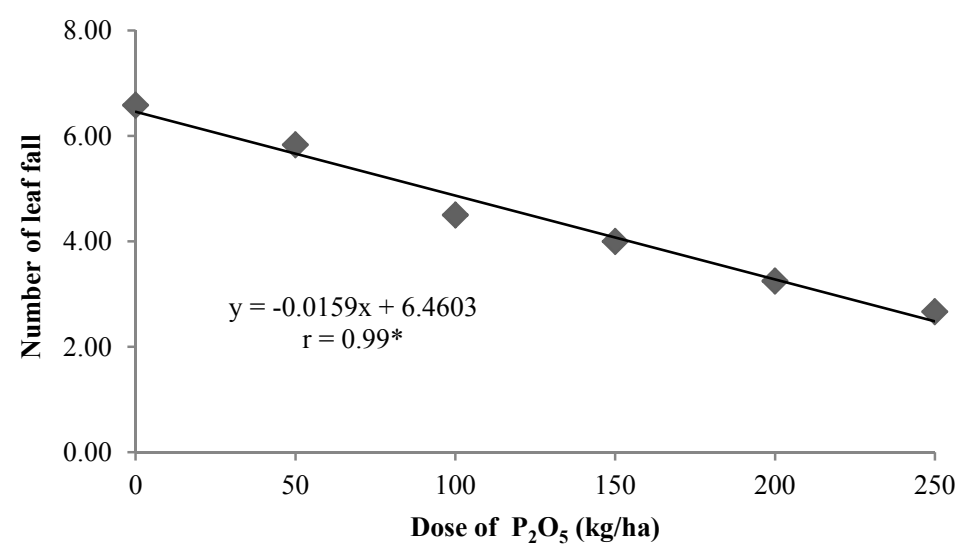

Figure 2. Response curve of the increasing dose of phosphorus on number of leaf fall

Number of Leaf Unfall (Leaf): Fertilization of $\mathrm{P}_{2} \mathrm{O}_{5}$ with doseto $250 \mathrm{~kg} /$ ha was still increasing the number of the leaf unfall from soybean plants. Nevertheless, the number of maximum unfall leaf was reached at the dose of $\mathrm{P}_{2} \mathrm{O}_{5}$ $213 \mathrm{~kg} / \mathrm{ha}$ with the number of leaf as many as 59 leaf (Figure 3). Musa (2010) also states that P fertilization of 100 $\mathrm{kg} / \mathrm{ha}$ had the highest number of leaves compared to those with no fertilizer on Kenaf plant. Application of $5 \mathrm{ppm}$ B increased the number of leaf unfall 5.96\% higher than that those without B (Table 1). Rio Tinto (2012) stated boron deficiency resulted in many changes in the anatomy of biochemistry and physiology of plants. Some functions boron is also associated with macro nutrients such as phosphorus, boron additions indirectly help $\mathrm{P}$ in cell development, strengthen the structure of cell walls and membranes so fewer leaves fall and leaves that persist on the plant for more. 


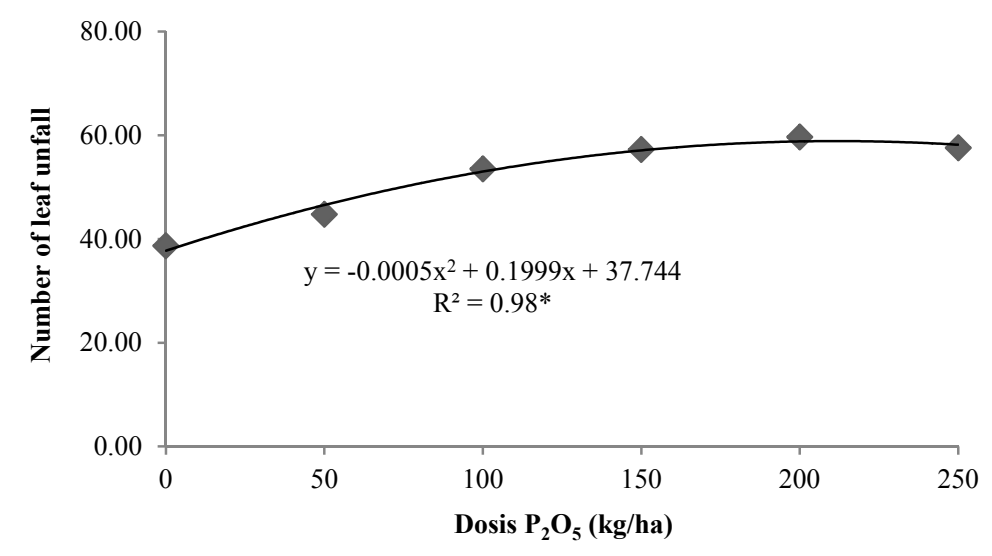

Figure 3. Response curve of the increasing dose of phosphorus on number of leaf unfall

Dry Weight of Plant (g): Fertilization of $\mathrm{P}_{2} \mathrm{O}_{5}$ with dose to $250 \mathrm{~kg} / \mathrm{ha}$ could increase dry weight of plant. At the dose of $0 \mathrm{~kg} / \mathrm{ha}$, the dry weight resulted was $29.51 \mathrm{~g}$ and increased by $0.076 \mathrm{~g}$ for every additional $1 \mathrm{~kg}$ of $\mathrm{P}_{2} \mathrm{O}_{5}$ (Figure 4). Application B with a concentration of $5 \mathrm{ppm}$ increased dry weight of plant $8.47 \%$ higher than those without $\mathrm{B}$ (Table 1). Fertilization of $\mathrm{P}$ is needed in large amounts by plants for division and cell enlargement in meristem tissue, then the meristem will generate new cells at the tip of the root or stem that resulted in increased plant height or length, the increase in plant height and number of leaf affects the light received by the plant so that it can improve the performance of photosynthesis and produce many photosynthate in forms of starch, lipids, and proteins. Photosynthate are translocated inside the plant so that it increases dry weight of the plant (Ndakidemi \& Dakora, 2007).

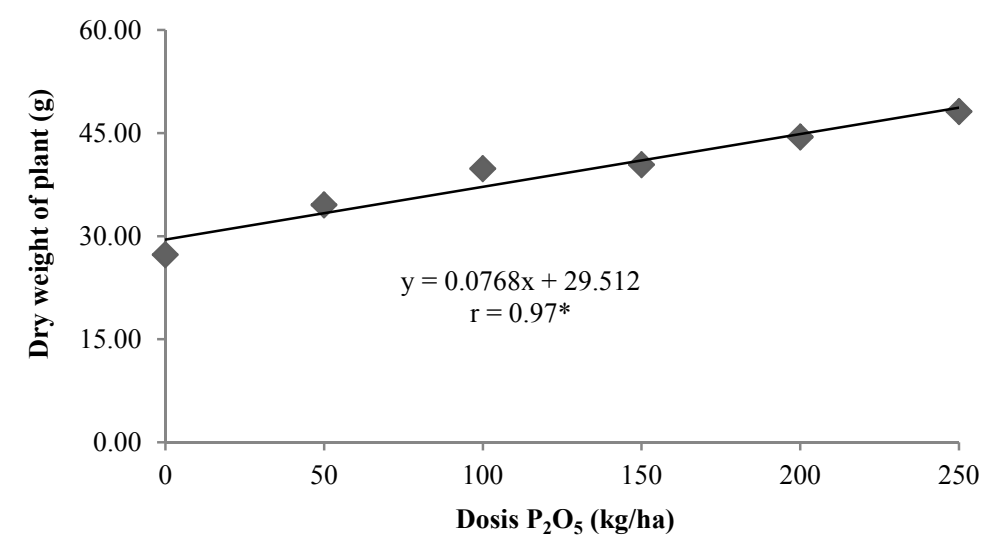

Figure 4. Response curve of the increasing dose of phosphorus on dry weight of plant

\subsection{Response of Plant Yield}

The observation on soybean yield components included total number of pods, number of filled pods, and a 100 grain weight sum. The results showed that the response of soybean yield to increased dose of $\mathrm{P}$ did not depend on the addition of $\mathrm{B}$ as shown by all variables of yield (Table 2 ). 
Table 2. Recapitulation of the increase in the dose of $\mathrm{P}$ and the addition of $\mathrm{B}$ on the soybean yield

\begin{tabular}{llll}
\hline \multirow{2}{*}{ Comparison } & \multicolumn{2}{c}{ Variable } \\
\cline { 2 - 4 } Boron (B) & TP & FP & 100G \\
P1: $\mathrm{B}_{0}$ Vs B1 & & \multicolumn{2}{c}{$6.41 *$} \\
Po (Phosphorus) & $\mathrm{ns}$ & $\mathrm{ns}$ & \\
P2: Po-Linear & & & $*$ \\
P3: Po-Quadratic & $*$ & $*$ & $\mathrm{Ns}$ \\
Interaction & $\mathrm{ns}$ & $\mathrm{ns}$ & $\mathrm{Ns}$ \\
P7: P1 $\times$ P2 & $\mathrm{ns}$ & $\mathrm{ns}$ & $\mathrm{Ns}$ \\
P8: $\mathrm{P} 1 \times \mathrm{P} 3$ & $\mathrm{~ns}$ & $\mathrm{~ns}$ & $\mathrm{Ns}$ \\
\hline
\end{tabular}

Note. $\mathrm{B}_{0}=0 \mathrm{ppm} \mathrm{B}, \mathrm{B}_{1}=5 \mathrm{ppm} \mathrm{B}, \mathrm{TP}=$ total number of pods, $\mathrm{FP}=$ number of filled pods, $100 \mathrm{G}=100$ grain weight, ${ }^{*}=$ significantly at $\alpha 0.05, \mathrm{~ns}=$ not significant.

Total Number of Pods: The results showed that fertilization of $\mathrm{P}_{2} \mathrm{O}_{5}$ with dose to $250 \mathrm{~kg} / \mathrm{ha}$ increased the total number of pods. At the dose of $50 \mathrm{~kg} / \mathrm{ha}$, the total number of pods pods produced reached 53 pods and increased by 26 pods each additional $50 \mathrm{~kg}$ of $\mathrm{P}_{2} \mathrm{O}_{5}$ (Figure 5). The total number of pods of soybean plants with the application of 5 ppm B was not different from those without B (Table 2). This is in paralel with research Morshed et al. (2008) who stated that the application of phosphorus to a dose of $125 \mathrm{~kg} / \mathrm{ha}$ produced the highest soybean growth and yield compared to the treatments without fertilizer. This is consistent with research Fandi et al. (2010) that the role of phosphorus in the growth of stems and leaf resulted in the number of flowers, better fruit forming to increase yield.

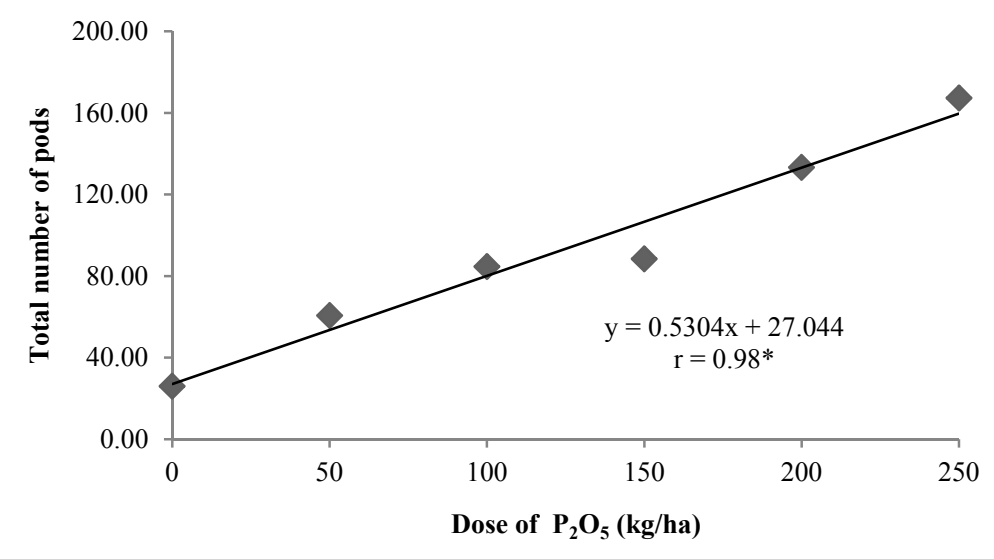

Figure 5. Response curve of the increasing dose of phosphorus on total number of pods

Number of Filled Pods: The results showed that fertilization of $\mathrm{P}_{2} \mathrm{O}_{5}$ with dose to $250 \mathrm{~kg} /$ ha produced filled pods to 163.38. At the dose of $50 \mathrm{~kg} / \mathrm{ha}$, filled pods produced reached 49 and increased 26 pods for each additional $50 \mathrm{~kg}$ of $\mathrm{P}_{2} \mathrm{O}_{5}$ (Figure 6). Application of $5 \mathrm{ppm} \mathrm{B}$ produced a number of filled pods which was not different than those without B (Table 2). Begum et al. (2015) said that the number of pods reached the highest with dose of P $54 \mathrm{~kg} / \mathrm{ha}$ as $54.49 \%$, higher than other treatments, and the lowest number of pods at a dose of P $0 \mathrm{~kg} / \mathrm{ha}$. 


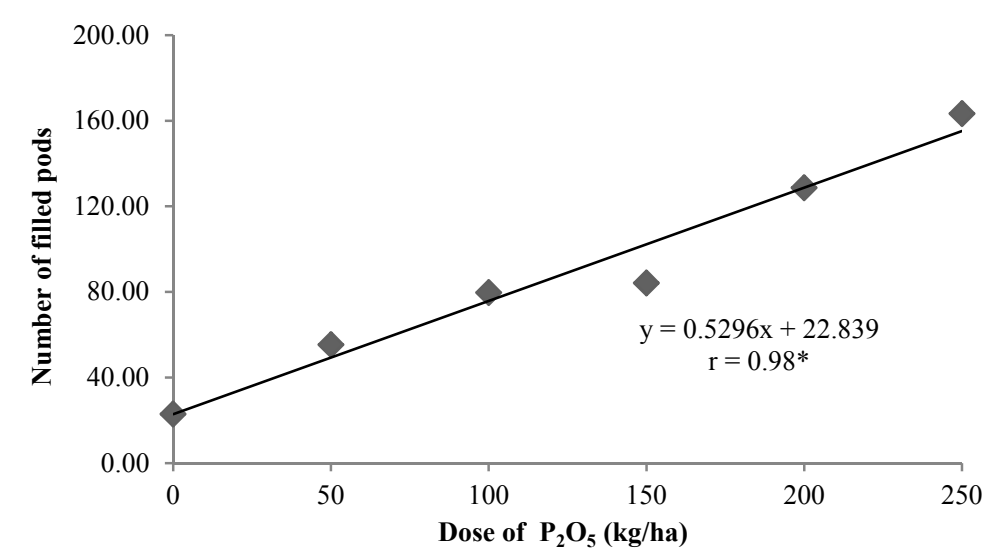

Figure 6. Response curve of the increasing dose of phosphorus on number of filled pods

100-Grain Weight $(\mathrm{g})$ : Fertilization of $\mathrm{P}_{2} \mathrm{O}_{5}$ with dose of $0 \mathrm{~kg} / \mathrm{ha}$, weight of 100 grain produced was $11.27 \mathrm{~g}$ and increased as $0.005 \mathrm{~g}$ of every additional $1 \mathrm{~kg}$ of $\mathrm{P}_{2} \mathrm{O}_{5}$ (Figure 7). This is in paralel with research of Thoyyibah et al. (2014) who stated that application of various doses of phosphate fertilizers in two soybean varieties had significant effect on grain weight per plant, Detam-1 variety which was cultivated $200 \mathrm{~kg} / \mathrm{ha}$ of phosphate fertilizers produced the highest weight $42.02 \mathrm{~g}$, equivalent to $3.5 \mathrm{ton} / \mathrm{ha}$ and had great significance with other combinations. Soybean plants with the application of $5 \mathrm{ppm} \mathrm{B} \mathrm{increased} \mathrm{weight} 100$ grain $6.41 \%$ higher than those without B (Table 2). The research of Bellaloui et al. (2013) indicated that the application of B through the leaves could increase the seed weight (100 grain weight) of $16.1 \mathrm{~g}$ higher than those without $\mathrm{B}$ of $13.2 \mathrm{~g}$ of soybean on treatment given water. This is in line with Rio Tinto (2012) stated that the addition of boron in plants could increase the success of flower pollination and had a role in seed formation, and application of boron on soybean plant increased the weight of 100 grain.

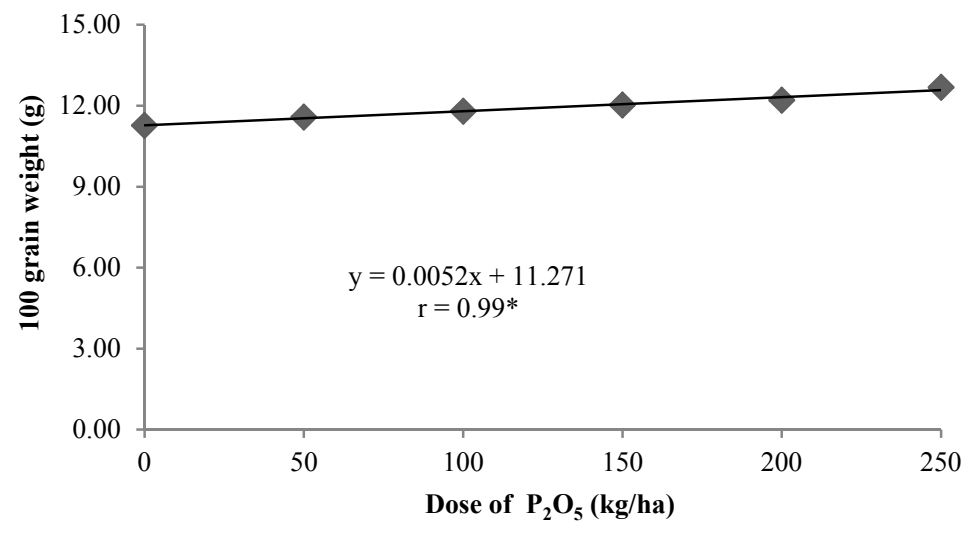

Figure 7. Response curve of the increasing dose of phosphorus on 100 grain weight

Quality of Soybean Seeds: The observation of soybean seeds components included germination, dry weight of normal seedling and vigor index. The results showed that the response of soybean seeds to increased dose of $\mathrm{P}$ did not depend on the addition of B or vice versa as shown by all variables of soybean seeds (Table 3 ). 
Table 3. Recapitulation of the increase in the dose of $\mathrm{P}$ and the addition of $\mathrm{B}$ on the soybean yield

\begin{tabular}{llll}
\hline \multirow{2}{*}{ Comparison } & \multicolumn{3}{c}{ Variable } \\
\cline { 2 - 4 } Boron (B) & G & DWNS & VI \\
P1: B $_{0}$ Vs B1 & & & \\
Po (Phosphorus) & $20.12 *$ & $21.26^{*}$ & $16.62^{*}$ \\
P2: Po-Linear & & & \\
P3: Po-Quadratic & $*$ & $*$ & $*$ \\
Interaction & $*$ & $*$ & $n$ \\
P7: P1 $\times$ P2 & $\mathrm{Ns}$ & $\mathrm{ns}$ & $\mathrm{ns}$ \\
P8: P1 $\times$ P3 & $\mathrm{Ns}$ & $\mathrm{ns}$ & $\mathrm{ns}$ \\
\hline
\end{tabular}

Note. $\mathrm{B}_{0}=0 \mathrm{ppm} \mathrm{B}, \mathrm{B}_{1}=5 \mathrm{ppm} \mathrm{B}, \mathrm{G}=$ germination, $\mathrm{DWNS}=$ dry weightof normal seedling, $\mathrm{VI}=$ vigor index,${ }^{*}=$ significantly at $\alpha 0.05, \mathrm{~ns}=$ not significant.

Germination (\%): Fertilization of $\mathrm{P}_{2} \mathrm{O}_{5}$ with dose to $250 \mathrm{~kg} / \mathrm{ha}$ increased the germination, but maximum germination was reached at the dose of $\mathrm{P}_{2} \mathrm{O}_{5} 226 \mathrm{~kg} / \mathrm{ha}$ as $84.97 \%$ (Figure 8). Application of $5 \mathrm{ppm} \mathrm{B}$ increased the germination $20.12 \%$ higher than those without B (Table 3). The results of Rosliani et al. (2012) stated that application of boron $1-4 \mathrm{~kg} / \mathrm{ha}$ could increase germination and growth potential maximum onion seed. The research result of Supriyanto et al. (2012) also showed that boron could increase the percentage of germination of sandalwood $19.32 \%$ compared with the control ( 0 ppm boron). In additional 400 ppm giving a best effect on vigor (growing speed) of sandalwood compared with control. Rio Tinto (2012) stated the need for B was much higher for reproductive growth than vegetative growth in most plant species, boron increased the production and retention of flowers, lengthening of pollen tubes, germination, and development of seeds and fruits.

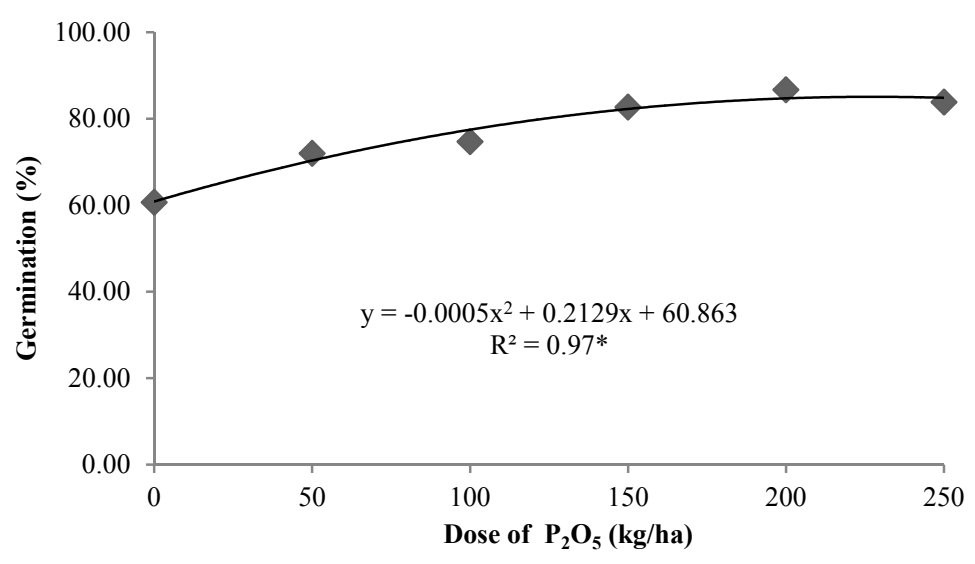

Figure 8. Response curve of the increasing dose of phosphorus on germination

Dry Weight of Normal Seedling (g): Fertilization of $\mathrm{P}_{2} \mathrm{O}_{5}$ with dose to $250 \mathrm{~kg} / \mathrm{ha}$ increased the dry weight of normal seedling, but maximum dry weight of normal seedling was achieved at the dose of $\mathrm{P}_{2} \mathrm{O}_{5} 169 \mathrm{~kg} / \mathrm{ha}$ as 1.99 $\mathrm{g}$ (Figure 9). Application of $5 \mathrm{ppm}$ B increased the germination $21.26 \%$ higher than those without B (Table 3). Lesilolo (2012) stated that the level of the grant of a phosphate (P1) had a value of percentage of germinated, vigor index and the dry weight of normal seedling lower than compared with the percentage value of the other four treatments (P2, P3, P4, P5). 


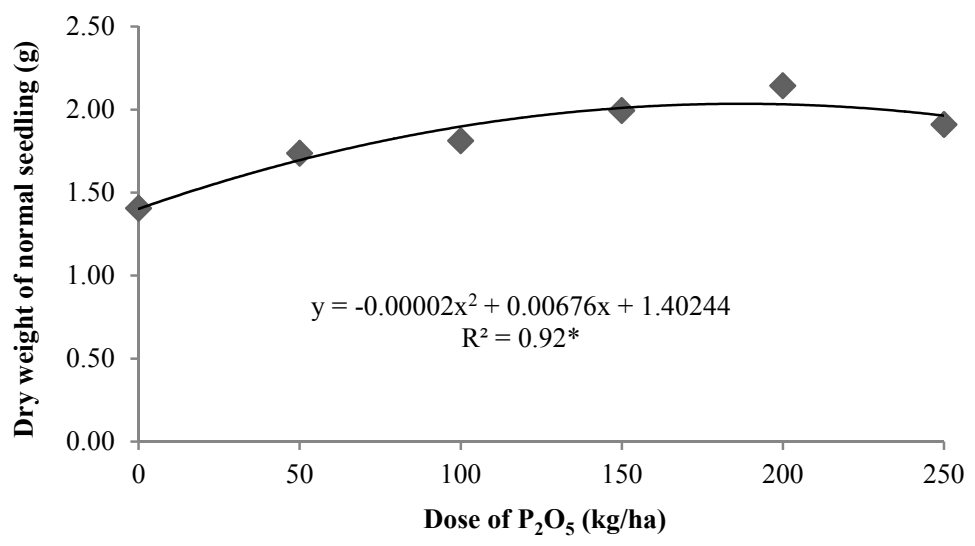

Figure 9. Response curve of the increasing dose of phosphorus on dry weight of normal seedling.

Vigor Index: Fertilization of $\mathrm{P}_{2} \mathrm{O}_{5}$ with dose to $250 \mathrm{~kg} / \mathrm{ha}$ increased the vigor index, but maximum vigor index was reached at the dose of $\mathrm{P}_{2} \mathrm{O}_{5} 198 \mathrm{~kg} / \mathrm{ha}$ as $36.38 \%$ (Figure 10). Application of $5 \mathrm{ppm} \mathrm{B}$ increased the germination $16.62 \%$ higher than those without B (Table 3). According to Perdana et al. (2014), the dry weight of seedling could determine the quality of the seed, if it had a large dry weight of seedling, it indicated that the seed had good quality. The height of the weight of the seed depended on the of the dry matter contained in the seed, the shape of the seed and the size of the seed.

Fageria (2009) stated low boron content in the plant would lead to decreased synthesis of cytokinin hormone (a hormone that works in germination) because in additional $400 \mathrm{ppm}$ giving a best effect on vigor (growing speed) of sandalwood compared with control because boron is an essential ingredient needed in the germination process of pollen grains and pollen tubes and it is indispensable for seeds to increase seed germination and vigor.

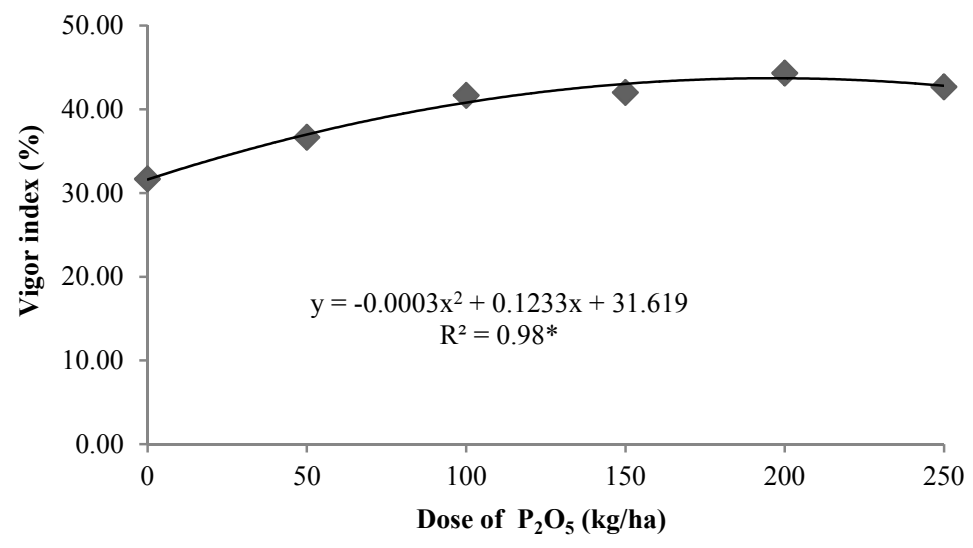

Figure 10. Response curve of the increasing dose of phosphorus on vigor index

\section{Conclusions}

Fertilization of $\mathrm{P}$ with dose to $250 \mathrm{~kg} / \mathrm{ha}$ was able to increase growth, yield and quality of soybean seeds on variable plant height, number of leaf unfall, dry weight of plant, total number of pods, number of filled pods, 100 grain weight, germination, dry weight of normal seedling. Application of 5 ppm B increased growth, yield and quality of soybean seed higher than those without B at a variable number of leaf unfall, dry weightof plant, 100 grain weight, germination, dry weight of normal seedling and vigor index. Response growth, yield and quality of soybean seeds to increased dose of $\mathrm{P}$ did not depend on the application of B shown by all the variables of growth, yield and quality of soybean seeds. 


\section{References}

Agustina, L. (2011). Nutrient Micro (Fe, Mn, Zn, Cu, B, Mo and Cl) Deficiency and Toxicity Needs Benefits (1st ed.). Post Graduate Program, Universitas Brawijaya, Indonesia.

Begum, M. A., Islam, M. A., Ahmed, Q. A., \& Rahman, M. M. (2015). Effect of nitrogen and phosphorus on the growth and yield performance of soybean. Journal of Agriculture, Livestock and Fisheries, 2(1), 35-42. https://doi.org/10.3329/ralf.v2i1.23027

Bellaloui, N., Hu, Y., Mengistu, A., Kassem, M. A., \& Abell, C. A. (2013). Effects of boron foliar application on seed composition, cell wall boron, and seed $\delta^{15} \mathrm{~N}$ and $\delta^{13} \mathrm{C}$ isotopes in water-stressed soybean plants. Front Journal of Plant Science, 4, 270. https://doi.org/10.3389/fpls.2013.00270

Central Bureau of Statistics. (2017). Bulletin of food consumptio. Data Center and Agricultural Information, $8(1), 34-38$.

Copeland, L. O., \& McDonald, M. B. (2001). Principles of Seed Science and Technology (4th ed.). Springer, Boston, MA. https://doi.org/10.1007/978-1-4615-1619-4

Fageria, N. K. (2009). The Use Nutrients in Crop Plant. CRC Press, Taylor and Francis Group, New York.

Fandi, M., Jalal, M., \& Munir, H. (2010). Effect of N, P, K concentrations on yield and fruit quality of tomato (Solanum lycopersicum L.) in tuff culture. Journal of Central European Agriculture, 11(2), 179-184. Retrieved from https://jcea.agr.hr/en/issues/article/788

Fitriesa, S., Maryati, S., \& Suhartanto, M. R. (2017). Effect of N, P, and K fertilization in two varieties of soybeans [Glycine $\max (\mathrm{L}$.$) Merr.] seeds on anthocyanin content in relation to seed vigor. Agrohorti$ Bulletin, 5(1), 117-125. https://doi.org/10.29244/agrob.5.1.117\%20-\%20125

ISTA (International Seed Testing Association). (2010). Seed Science and Technology. International Rules for Seed Testing, Zurichstr, Switzerland.

Jayasumarta, D. (2012). Effect of tillage systems and fertilizer P on growth and yield of soybean (Glycine max L. Merrill). Agrium Journal, 17(3), 148-154. Retrieved from http://jurnal.umsu.ac.id/index.php/agrium/article/ view/313/271

Julita, S., \& Hayati, R. (2016). Effect of foliar application of nitrogen and boron on quality of soybean seed [Glycine $\max$ (L.) Merril]. Floratek Journal, 11(1), 10-17. https://doi.org/10.24815/floratek.v11i1.4550

Lesilolo, M. K. (2012). Phosphate fertilization study on viability and vigor of corn seed (Zea mays L.) Hulaliu varieties. J. Agrologia, 1(2), 119-125. Retrieved from https://ejournal.unpatti.ac.id/ppr_paperinfo_lnk. php? id $=346$

Morshed, R. M., Rahman, M. M., \& Rahman, M. A. (2008). Growth nd yield of soybean (Glycine max L.) as influenced by phosphorus. Bangladesh Journal Sci. Ind. Res., 43(3), 359-368. https://doi.org/10.3329/ bjsir.v43i3.1151

Musa, M. H. (2010). Effects of nitrogen, phosphorus, and potassium levels on kenaf (Hibiscus cannabinus L.) growth and photosynthesis under nutrient solution. Journal of Agricultural Science, 2(2), 49-57. https://doi.org/10.5539/jas.v2n2p49

Ndakemi, P. A., \& Dakora, F. D. (2007). Yield components of nodulated cowpca(Vigna unguiculata [L.] Walp) and maize (Zea mays) plants grown with exogenous phosphorus in different cropping systems. Aust. J. Exp. Agric., 47, 587-590. https://doi.org/10.1071/EA05274

Perdana, J. L., Aslim, R., \& Elza, Z. (2014). Effect of several doses of phosphorus fertilizer (P) on the quality of various soybean cultivars (Glycine max L. Merril) during filling and seeding. J. University of Riau., 1(1), $1-12$.

Permadi, K., \& Haryati, Y. (2015). Provision of N, P, K fertilizers based on site specific nutrient management to increase sobean productivity. Agrotropika Journal, 5(1), 1-18.

Razaq, M., Pheng, Z., Hai-Long, S., \& Salahuddin. (2017). Influence of nitrogen and phosphorus on the growth and root morphology of Acer mono. PLoS ONE, 12(2), e0171321. https://doi.org/10.1371/journal.pone. 0171321

Rio Tinto. (2012). Functions of Boron in Plant Nutrition. Agronomy Note. Retrivied July 27, 2017, from https://www.researchgate.net/profile/Anoop_Srivastava7/post/What_is_the_role_of_boron_in_seed_produc

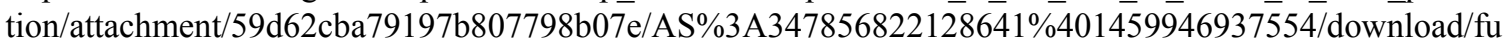


nctionsofboroninplantnutrition-final-feb2012.pdf

Rosliani, R., Palupi, E. R., \& Hilman, Y. (2012). The use of benzyl amino purin and boron to increase the production of true shallots seed seed quality onion in Allium cepa var Ascalonicum. J. Hort., 22(3), 242-250. https://doi.org/10.21082/jhort.v22n3.2012.p242-250

Sihaloho, N., Rahmawati, N., \& Princess, L. A. (2015). Response of growth and production of soybean varieties detam 1 against the provision of vermicompost and fertilizer P. Jurnal Agroteknologi, 3(4), 1591-1600. Retrieved from https://jurnal.usu.ac.id/index.php/agroekoteknologi/article/view/11811/5151

Sudaryono, T. (2017). Onion response to boron fertilizing. Agrika Journal, 11(2), 161-169. Retrieved from http://publishing-widyagama.ac.id/ejournal-v2/index.php/agrika/article/view/485/464

Supriyanto, Selly, M. A., \& Benny, S. (2012). The influence of boron and immersion on seed germination of Cendana (Santalum album Linn.). J. Tropical Silviculture, 3(3), 182-186. Retrieved from http://download. portalgaruda.org/article.php? article $=85325 \& \mathrm{val}=228$

Thoyyibah, S., Sumadi, \& Nuraini, A. (2014). Effect of phosphate fertilizers on growth, yield components, yield and quality of seeds of two varieties of soybean (Glycinemax (L.) Merr.) in Inceptisol Jatinangor. Agriculture Science Journal, 1(4), 111-121. Retrieved from http://download.portalgaruda.org/article.php?article=256414 $\&$ val $=6090 \&$ title $=$ PENGARUH $\% 20$ DOSIS $\% 20$ PUPUK $\% 20 F O S F A T \% 20$ TERHADAP $\% 20$ PERTUMBU HAN, \%20KOMPONEN\%20HASIL, \%20HASIL \%20DAN\%20KUALITAS\%20BENIH\%20DUA\%20VA RIETAS\%20KEDELAI\%20(Glycine\%20max\%20(L.)\%20Merr.)\%20PADA\%20INCEPTISOL\%20JATIN ANGOR

\section{Copyrights}

Copyright for this article is retained by the author(s), with first publication rights granted to the journal.

This is an open-access article distributed under the terms and conditions of the Creative Commons Attribution license (http://creativecommons.org/licenses/by/4.0/). 